\title{
Turmeric (Curcuma Longa L): An Unpopular Industrial Crop for Sustainable Agriculture
}

Akpan I*
Michael Okpara University of Agriculture, Nigeria

*Corresponding author: Idaresit Akpan, Michael Okpara University of Agriculture, Nigeria, Tel: 07034544445; Email: idaresitidung@yahoo.com

\section{Review Article}

Volume 3 Issue 7

Received Date: July 20, 2018

Published Date: August 31, 2018

\section{Abstract}

There is a dearth of information in Nigeria on turmeric as an industrial crop with the potential of creating a wide range of employment opportunities due to its overwhelming benefits. Turmeric contains an orange pigment called curcumin has anti-cancer, anti-bacterial, anti-fungal, anti-inflammatory, anti-tumor, anti-viral, anti-depressant and anti-oxidant effects. It is also a natural painkiller and lever detoxifier. If turmeric production is considered in sustainable way it can create wealth and employment for millions of people as well as promote healthcare to the present teaming population.

Keywords: Agriculture; Curcuma Longa L; Turmeric

\section{Introduction}

Agriculture was the main stay of Nigerian economy during the colonial and up to the early 1970s when crude oil was struck before it was relegated to the background. The resultant effect was dependence on importation of food stuffs which increased import bills of the country and greatly impoverished the economy. The country's gates were thrown open for food importation and the local food production declined as a result of depressed domestic prices. Apart from the politics associated with the importation, there was massive rural- urban drift of young men and women who abandoned food production to elderly small scale farmers only capable of cropping less than 2.0 hectares of land using traditional methods and implements. A lot of measures have been put in place to improve food production in the country. They include establishment of universities of agriculture, agricultural research institutes, agricultural cooperative bank, and agricultural insurance company. Others included fertilizer manufacturing company, agricultural development projects (ADPs) and agricultural seeds council (NASC). The resultant impact was the production of soil maps, improved seeds and development of traditional farming systems for the different agro-ecologies with present emphasis in making agriculture a profitable venture capable of contributing to the gross national product (GNP).

Presently agricultural production has gone beyond that for food, animal feedstuff and fiber production to that of industrialization and sustainability. Sustainable agriculture according to USDA refers to farming systems that are capable of maintaining their productivity and usefulness in the society indefinitely by being resource conserving, socially supportive, commercially competitive and environmentally sound. It is the farming system which is in vogue now because it allows more people to stay on the lands while strengthening rural commitments and integration of humans with their environments. It has 


\section{Open Access Journal of Agricultural Research}

the capability of producing diverse forms of high quality foods, fibers and medicines. It is also capable of preserving biodiversity, maintain soil fertility and water purity without preventing recycling of natural resources and conservation of energy.

Other benefits of sustainable agriculture include the critical role consumers can play in creating a sustainable food system through their purchase which is transmitted to producers, retailers and others in the value chain about what they think is important to produce to mention a few.

This paper is purposed to review the potentials of turmeric (curcuma longa L) as an unpopular industrial crop for Sustainable Agriculture.

\section{Turmeric Curcuma Longa $\mathbf{L}$}

Turmeric is a spice as well as a medicinal plant of economic importance which belongs to the family of ginger. Out of the four species of the crop, Curcuma longa is the widely cultivated type. The plant contains essential oils with over 40 constituents in the rhizome and over 60 in the leaf [1]. The essential ingredients in the rhizome include 1.8-5.4 \% curcumin pigment and 2.5-7.2\% essential oil, $69.34 \%$ carbohydrate, $6.3 \%$ protein, $3.5 \%$ minerals and other important elements on dry weight basis Kumar, et al. and Ologede, et al. [2,3].

It is native to Indonesia and southern India in tropical south-east Asia where it has been an important part of Eastern cultural traditions, including traditional Chinese medicine and Ayurveda for over 2500 years ago from where it perhaps spread to the Americas, Africa and other parts of the world including Nigeria [4,5]. Turmeric can be grown in diverse tropical climatic conditions from sea level to $1,500 \mathrm{~m}$ and above. It does not withstand waterlogging and shading. The best time of planting turmeric is between March and May at temperature of $20-30^{\circ} \mathrm{C}$ and annual rainfall ranging between $1500-2250 \mathrm{~mm}$ on loamy or loose-friable-fertile alluvial soil [6]. The crop sprouts in14-21 days after planting (DAP) and takes 9-10 months to mature. Turmeric is often intercropped with grains, legumes and tree crops for increased total benefit although experiments have proved that planting turmeric sole is better than in combination with another crop [7].

A yield of 20-25 tonnes/ha can be obtained depending on variety, cropping system, size and type of rhizome planted and management capacity. Sole turmeric yield can be increased by $28.4 \%$ on treatment receiving no fertilizer while the treatment receiving 120:120 NK can bring about $69.8 \%$ increase. Where straight fertilizers are hard to come by, application of $350-400 \mathrm{~kg} / \mathrm{ha}$ NPK 20:10:10 fertilizer 4 months after planting (MAP) can be substituted [8]. It is better to apply the first dose of 300 $\mathrm{kg} / \mathrm{ha} 1 \mathrm{MAP}$ and the second dose, $4 \mathrm{MAP}$, as top dressing.

Akinpelu, et al. estimated that for every 1.00 spent on turmeric production, about $\$ 2.33$ is realized [9]. Akpan, et al. in estimating the productivity of turmeric production observed that the cultivation of turmeric is more productive and profitable when planted sole and that the effort is capable of generating an income of about \# 5 million/ha [7].

\section{Uses of Turmeric}

\section{Income Generation}

The whole turmeric plant is useful: The fresh turmeric rhizome (Figure 1) is a money maker as a kilogram sells for up to $\mathrm{N} 1,000.00$ in the open market. It can be dried and marketed world-wide as well while the top can be processed into cosmetics or incorporated into fertilizers, pesticides and animal feed.

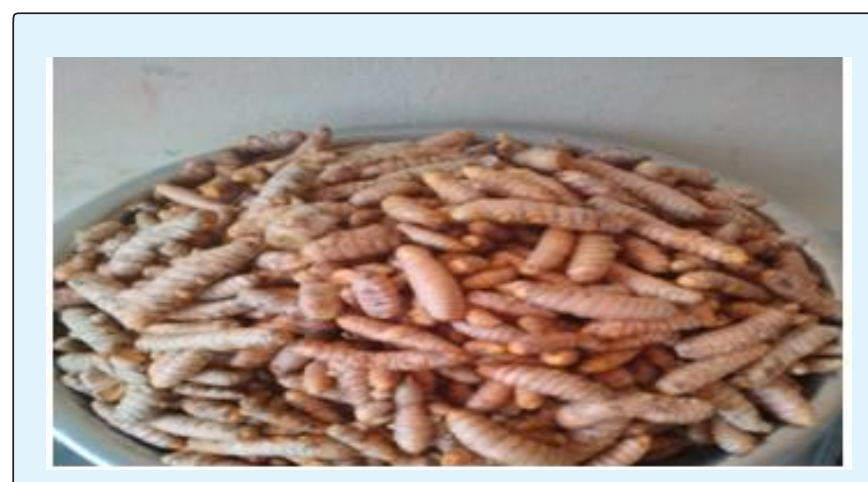

Figure 1: Fresh Turmeric Rhizome.

\section{Health Benefits}

It is the uses of turmeric which gives it sustainability status amidst other crops. It has a broad-spectrum natural anti-biotic effect without side effect. It has an enlarged health benefits ranging from anti-cancer, anti-bacterial, anti-fungal, anti-inflammatory, anti-tumor, anti-viral, antidepressant and anti-oxidant effects. It is also a natural painkiller and lever detoxifier.

\section{Uses in the Pharmaceutical Industry}

Some pharmaceutical companies are now producing turmeric based drugs such as Curcumin 2000 capsule, Bioperine capsule, etc for money. 


\section{Open Access Journal of Agricultural Research}

\section{Uses in the Cosmetic Industry}

Turmeric has natural antiseptic and anti-bacterial properties useful in disinfecting cuts and burns, speedsup healing of wounds, pimples and ringworm. It helps in remodeling damaged skin, treatment of psoriasis, healing of inflammatory skin conditions and stops the growth of new blood cells in tumors.

\section{Uses in the Food and Beverage Industry}

It is used as spice on meat, food of all kinds and as a preservative. It can be processed into powder (Figure 2), food drinks and wine. Turmeric turns white rice to a beautiful orange color when boiled.

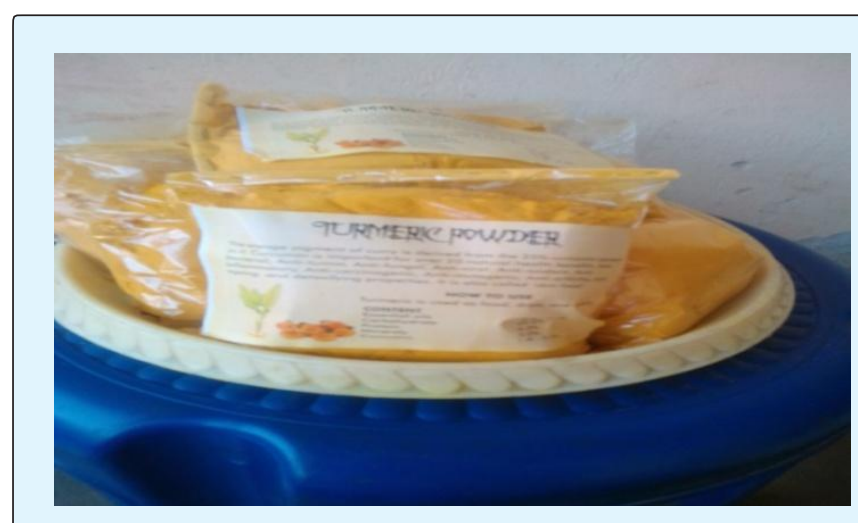

Figure 2: Turmeric Powder.

\section{Uses in the Textile Industry}

It is a natural dye and indicator. It shows yellow on $\mathrm{pH}$ 7.4 and bright red on pH 5.6 and below. It is being used as a dye in the traditional weaving industry.

\section{Uses in the Agro-Allied Industry}

Turmeric is a natural ant repellent good for the production of insecticide and agro-allied products. As an indicator therefore, turmeric can be used by the rural farmer to differentiate between acidic and alkaline soils.

\section{Laboratory Uses}

It is currently employed as a reagent by Laboratory Technologists in the Biochemistry and Microbiology analytical programs.

\section{Conclusion}

Production and processing of turmeric is a profitable venture because of its numerous means of utilization. For the purpose of sustainability, efforts must be made to develop innovative ways of harnessing the in-exhaustive value chain of turmeric.

\section{References}

1. Sharma RK, Misra BP, Sarma TC, Bordoloi AK, Pathak MG, et al. (1997) Essential Oils of Curcuma longa L from Bhutan. Journal of Essential Oil Research 5(9): 589-592.

2. Kumar N, Khader JBMMA, Rangaswami P, Irulappan I (1993) Introduction to spices, plantation crops, medicinal and aromatic plants. Oxford \& IBH publishing Co Pvt Ltd New Delhi, pp: 278.

3. Olojede AO, Nwokocha CC, Dalyop T (2006) Effect of variety, rhizome and seedbed type on yield of turmeric (Curcuma longa L.) under Umudike condition. In: Asumugha GN, Olojede AO, Ikeorgu JG, Ano AO, Herbert U (Eds), Repositioning agriculture for sustainable millennium development goals in Nigeria. Proceedings of the 40th Ann Conf of the Agric Soc of Nigeria, NRCRI Umudike, Abia State, Nigeria, pp. 691-693.

4. Iyeyi A (2008) Staying Healthy with Turmeric. A Journal of African Medicine 3(4): 40.

5. HealthDairies.com (2011) Health benefits of turmeric. Health Benefit of Turmeric.

6. Pulseglove JW (1974) Tropical crops (Dicotyledons) Longman scientific and technical. Longman Group UK, Ltd.

7. Akpan II, Muoneke CO, Okpara DA (2012) Effect of egusi Planting Density on Productivity of Egusi/Turmeric Intercrops in Southeastern Nigeria. Asian Journal of Crop Science 5 (1): 41-47.

8. Akpan II, Muoneke CO, Okpara DA (2013) Effect of N $P$ K Fertilizer Rates on the Productivity of Egusi/Turmeric Intercrop in South-eastern Nigeria. International Journal of Applied Technology 2(9).

9. Akinpelu AO, Mbanaso EO, Olojede AO, Obasi C, Amaefula A (2008) Proceedings of the 42nd Annual Conf of the Agric Soc of Nigeria, Ebonyi State Univ, Abakaliki, Ebonyi State pp: 400-402. 